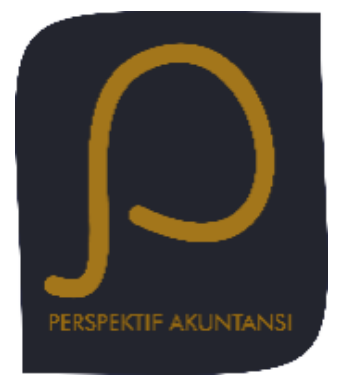

Perspektif Akuntansi

Volume 3 Nomor 1 (Februari 2020), hal. 61-83

ISSN: 2623-0194 (Print), 2623-0186 (Online)

Copyright(C) The Authors(s). All Rights Reserved

Fakultas Ekonomika dan Bisnis,

Universitas Kristen Satya Wacana

DOI: https://doi.org/10.24246/persi.vXiX.p61-83

http://ejournal.uksw.edu/persi

\title{
Pengukuran Kesiapan Literasi Digital Usaha Mikro Kecil dan Menengah (UMKM) Terhadap Pelaporan Pajak Elektronik
}

\author{
M. Devitia Putri Nilamsari ${ }^{1}$ \\ Alexandra Adriani Widjaja \\ Shandy Jannifer Matitaputty \\ Universitas Katolik Soegijapranta Semarang
}

Received Abstract. Nowadays, Micro Small and Medium Enterprises 28/07/2020 (MSMEs) are faced the tax reporting that start requiring

Accepted $10 / 08 / 2020$ taxpayers to report their taxes electronically. The digital capability of a business entity including MSMEs are suspected to have an influence on its administrative oblihations, which include MSMEs tax reporting obligations. This study aims to measure the readiness of MSMEs digital literacy towards electronic tax reporting in Semarang as seen from the MSMEs digital literacy profile and whether there is a correlation between digital literacy and their electronic tax reporting. This study uses primary data which collected by questionnaire with MSMEs subjects that incorporated in the Womanpreneur Community (WPC) of Semarang. The results showed that WPC Semarang, digital literacy has a weak correlation with electronic tax reporting. In addition, the interest of MSMEs to report electronic tax obligations are weakly correlated with their technical ability to use computer. In other words, the technical ability factor does not become a barrier for MSMEs to fulfill tax obligations electronically.

Keywords: Micro Small and Medium Enterprises (MSMEs), Digital Literacy, Electronic Tax Reporting

1 devitia@unika.ac.id 


\begin{abstract}
Abstrak. Usaha Mikro Kecil dan Menengah (UMKM) saat ini dihadapkan dengan pelaporan pajak yang mulai mewajibkan Wajib Pajak untuk melaporkan pajaknya secara elektronik. Kemampuan digital UMKM diduga memberikan pengaruh terhadap kewajiban administratif yang mana termasuk kewajiban pelaporan pajak UMKM. Penelitian ini bermaksud mengukur kesiapan literasi digital UMKM terhadap pelaporan pajak elektronik di Kota Semarang yang dilihat dari profil literasi digital UMKM dan ada tidaknya korelasi antara literasi digital dengan pelaporan pajak elektronik mereka. Penelitian ini menggunakan data primer yang dikumpulkan menggunakan kuesioner dengan subjek UMKM yang tergabung dalam Womanpreneur Community (WPC) Kota Semarang. Hasil penelitian ini menunjukkan bahwa pada pelaku UMKM yang tergabung dalam kelompok WPC, literasi digital memiliki korelasi yang lemah terhadap kesiapan pelaporan pajak secara elektronik. Minat para pelaku UMKM yang tergabung dalam kelompok WPC untuk melaporkan kewajiban pajak secara elektronik berkorelasi lemah dengan kemampuan teknis mereka dalam menggunakan komputer. Hal ini membuktikan bahwa faktor kemampuan teknis tidak menjadi penghalang bagi para responden untuk memenuhi kewajiban perpajakan secara elektronik.
\end{abstract}

Kata kunci: Usaha Mikro Kecil dan Menengah (UMKM), Literasi Digital, Pelaporan Pajak Elektronik

\title{
Pendahuluan
}

Semarang tercatat sebagai kota dengan jumlah Usaha Mikro Kecil Menengah (UMKM) terbanyak di Jawa Tengah. Berdasarkan data Antaranews Jateng, Dinas Koperasi dan UMKM menyebutkan bahwa saat ini terdapat lebih dari empat belas ribu UMKM di Kota Semarang dengan pertumbuhan rata-rata sekitar dua ribu UMKM di setiap tahunnya (Zuhdiar, 2019). Banyaknya jumlah UMKM membuat peran mereka menjadi penting dalam perekonomian Kota Semarang. Peran UMKM telah teruji ketika Indonesia menghadapi krisis global. Jumlah yang banyak tersebut membuat UMKM mampu menyerap tenaga kerja dengan jumlah yang banyak pula. Selain berperan dalam penyerapan tenaga kerja, keberadaan UMKM akan memberikan kontribusi tersendiri dalam penerimaan pajak. 
Pada praktiknya, sistem perpajakan di Indonesia menganut sistem selfassessment yang menuntut kemampuan wajib pajak untuk menghitung, menyetor, dan melapor sendiri kewajiban perpajakannya. Dalam pelaporan pajak mulai diterapkan pelaporan pajak secara elektronik baik menggunakan e-filling maupun e-form. Penerapan pelaporan pajak secara elektronik menuntut kemampuan wajib pajak memiliki kemampuan digital.

Kemampuan digital yang dikenal juga dengan istilah literasi digital merupakan pengetahuan dan kecakapan untuk menggunakan media digital, media komunikasi, serta jaringan dalam menemukan, membuat informasi, mengevaluasi, dan memanfaatkannya secara sehat, bijak, cerdas, cermat, tepat, dan patuh hukum guna membina komunikasi dan interaksi dalam kehidupan sehari-hari (Kemdikbud, 2017). Kemampuan digital seseorang atau suatu badan usaha seperti UMKM diduga akan memberikan manfaat tersendiri bagi pengusaha tersebut baik dalam hal pengembangan tata kelola usaha maupun pelaksanaan kewajiban administratifnya, termasuk juga pelaporan pajaknya. Adapun adaptasi teknologi melalui pemahaman digital menjadi hal pokok yang dapat dilakukan untuk meningkatkan produktivitas suatu entitas atau sektor publik (Holzer dan Kathe, 1998). Digitalisasi organisasi khususnya UMKM hanya dapat dilakukan apabila anggota UMKM tersebut sudah melek digital atau terbiasa memanfaatkan teknologi dalam kesehariannya, namun apabila kondisi ini belum tercapai maka perlu dilakukan literasi digital. Dengan demikian, pengembangan UMKM tersebut pun dapat dilakukan dengan optimal.

Penelitian ini bertujuan mengukur kesiapan literasi digital UMKM terhadap pelaporan pajak elektronik di Kota Semarang pada salah satu kelompok UMKM di Kota Semarang adalah Womanpreneur Community (WPC). Kelompok UMKM ini beranggotakan UMKM wanita, saat ini anggota UMKM WPC yang aktif mencapai 150 anggota dengan jenis usaha yang beraneka ragam. Organisasi ini merupakan organisasi non-profit sebagai wadah bagi sahabat perempuan dalam meningkatkan kemandirian dan pemberdayaan ekonomi. Perempuan yang menjalankan usaha akan menolong rumah tangga untuk memiliki lebih dari satu sumber penghasilan dalam rumah tangga tersebut, sehingga keuangan rumah tangga tidak bergantung sepenuhnya kepada suami. Berdasarkan wawancara dengan ketua WPC, didapati bahwa para anggota WPC memiliki kemauan untuk belajar hal baru yang cukup tinggi. Hal ini sangat terkait dengan tuntutan perubahan jaman dimana kemajuan jaman mendorong UMKM untuk beradaptasi dan mengembangkan dirinya. Hal ini juga sangat terkait dengan peraturan perpajakan yang sangat dinamis dan berubah sesuai dengan perubahan jaman. 
Secara lebih mendalam, penelitian ini bertujuan untuk mengetahui profil digital UMKM di Kota Semarang dan mengukur ada tidaknya korelasi antara keahlian menggunakan komputer dengan kesiapan pelaporan pajak elektronik khususnya pada kelompok UMKM yang tergabung dalam Womanpreneur Community. Adapun masalah penelitian terkait penjabaran tersebut yaitu (1) Bagaimana profil digital UMKM di Kota Semarang khususnya pada kelompok UMKM yang tergabung dalam Womanpreneur Community? (2) Apakah terdapat korelasi antara keahlian menggunakan komputer dengan kesiapan pelaporan pajak elektronik khususnya pada kelompok UMKM yang tergabung dalam Womanpreneur Community? Penelitian ini berguna untuk memberikan potret profil literasi digital UMKM di Kota Semarang dan menemukan ada tidaknya keterkaitan antara keahlian menggunakan komputer dengan kesiapan pelaporan pajak elektronik khususnya bagi UMKM wanita di Kota Semarang sehingga dapat menjadi masukan bagi pemerintah kota maupun akademisi dan pusat studi dalam bidang ekonomi dan perpajakan.

\section{Telaah Pustaka}

\section{Usaha Mikro Kecil dan Menengah (UMKM)}

UMKM merupakan bentuk usaha yang berdiri sendiri baik yang dilakukan oleh perorangan maupun badan usaha di semua sektor ekonomi. Di Indonesia, karakteristik UMKM ditandai dengan pembentukan modal yang tidak besar, tenaga kerja tidak dituntut berpendidikan formal tertentu, sebagian besar berlokasi di pedesaan dan tidak memerlukan infrastruktur, serta memiliki ketahanan yang kuat ketika Indonesia dilanda krisis ekonomi (Nasikin, 2016). Berdasarkan Undang-Undang Nomor 20 Tahun 2008 tentang UMKM, usaha mikro didefinisikan sebagai suatu usaha produktif yang dimiliki baik perorangan ataupun badan usaha perorangan dengan memenuhi kriteria kekayaan bersih paling banyak Rp50.000.000 atau memiliki total omzet paling banyak Rp300.000.000 per tahun. Sedangkan usaha kecil merupakan suatu bentuk kegiatan atau usaha produktif yang berdiri sendiri dan dilakukan baik oleh orang perseorangan ataupun badan usaha dengan memenuhi kriteria kekayaan bersih Rp50.000.000 sampai Rp500.000.000 atau memiliki total omzet Rp300.000.000 sampai Rp2.500.000.000 per tahun. Usaha menengah yaitu suatu usaha produktif yang berdiri sendiri dan dilakukan oleh orang perseorangan atau badan usahadengan memenuhi kriteria kekayaan bersih Rp500.000.000 sampai Rp10.000.000.000 atau memiliki total omzet lebih dari Rp2.500.000.000 sampai Rp50.000.000.000 per tahun (Kuncoro, 2010).

UMKM cenderung banyak menghadapi masalah baik ketika proses merintis maupun mengelola serta mengembangkannya. Adapun salah satu masalah yang sering dihadapi dan bahkan menjadi permasalahan yang serius adalah 
keterbatasan SDM lebih pada kurangnya pemahaman dan kemampuan dari SDM dalam memanfaatkan fasilitas digital yang tersedia, sebagai contoh komputer yang diharapkan dapat membantu proses pencatatan dan pelaporan baik keuangan maupun perpajakan (Tambunan, 2002). Dengan demikian, keterbatasan tersebut disinyalir dapat berdampak pada kurangnya kemampuan UMKM untuk bersaing di pasar domestik maupun internasional sehingga dibutuhkan pengelolaan dan pengembangan yang lebih optimal bagi UMKM di Indonesia.

\section{Pengembangan hipotesis}

UMKM berperan penting dalam perekonomian termasuk dalam penerimaan pajak UMKM. Pada praktiknya, UMKM dihadapkan pada pelaporan pajak mulai mewajibkan wajib pajak untuk melaporkan pajaknya secara elektronik dan online. Dalam hal ini wajib pajak dituntut untuk memiliki pengetahuan dan kecakapan untuk menggunakan media digital, alat-alat komunikasi, atau jaringan dalam menemukan, membuat informasi, mengevaluasi dan memanfaatkannya secara sehat, bijak, cerdas, cermat, tepat, dan patuh hukum guna membina komunikasi dan interaksi dalam kehidupan sehari-hari (Kemdikbud, 2017).

Kemampuan atau literasi digital pada konteks ini yaitu kemampuan untuk memahami, mengevaluasi dan mengintegrasikan informasi dalam berbagai format yang dapat disampaikan oleh komputer. Adapun tingkat kecemasan terhadap penggunaan komputer (computer anxiety) menyebabkan seseorang menjadi kurang memiliki kepercayaan diri sehingga cenderung menutup diri dan tidak bersedia untuk memahami atau menerima penggunaan perangkat komputer. Hal ini berdampak pula pada hasil kinerja yang rendah (Rustiana, 2004). Sedangkan apabila seseorang memiliki pemahaman terkait prinsipprinsip dasar komputer, sistem operasi komputer, dan kecakapan menggunakan perangkat lunak tertentu maka tingkat keahlian penggunaan perangkat digital pun cenderung lebih tinggi (Indriantoro, 2000). Desmayanti (2012) juga menambahkan bahwa kesiapan teknologi informasi juga mempengaruhi kemajuan pola pikir individu dimana semakin siap individu dalam menerima teknologi yang baru maka semakin maju pula pemikirannya terutama dalam beradaptasi dengan teknologi yang semakin berkembang.

Dengan demikian, kemampuan digital suatu badan usaha termasuk UMKM dapat memberikan manfaat tersendiri bagi para pelaku usaha terutama dalam pelaksanaan kewajiban administratifnya yaitu termasuk kewajiban pelaporan pajak UMKM dimana pelaporan pajak tersebut cenderung dilaporkan secara online atau elektronik. Hal ini juga didukung oleh pendapat Desmayanti (2012) yang menyatakan bahwa kesiapan teknologi pada dasarnya dipengaruhi oleh 
individu itu sendiri, apakah dari dalam diri individu siap menerima teknologi khususnya dalam hal ini pelaporan pajak elektronik. Apabila seseorang dapat menerima sebuah teknologi dengan baik maka ia cenderung tidak ragu-ragu untuk melaporkan pajak secara elektronik. Secara lebih lanjut Andi (2018) juga berpendapat bahwa apabila wajib pajak dapat menerima sebuah teknologi baru maka wajib pajak tersebut tidak ragu-ragu untuk melaporkan pajaknya secara elektronik (menggunakan e-filling). Berdasarkan penjabaran tersebut, maka hipotesis yang dapat disusun adalah sebagai berikut.

H: Kesiapan literasi Digital UMKM memiliki korelasi terhadap pelaporan pajak elektronik

\section{Metoda}

\section{Jenis dan Sumber Data}

Jenis penelitian ini adalah formal study dengan melakukan pengujian hipotesis atas hipotesis kausal yang telah dirumuskan sebelumnya. Oleh sebab itu, penelitian ini merupakan penelitian kuantitatif. Adapun metode pengumpulan data penelitian dengan data primer menggunakan kuesioner. Kuesioner mewakili persepsi dari masing-masing individu sehingga unit analisis yang dilakukan juga secara individu. Adapun kedalaman penelitian adalah kurang namun dengan tingkat generalisasi yang tinggi karena menggunakan studi statistik. Dimensi waktu dalam penelitian ini yaitu cross sectional dimana hanya melibatkan satu waktu tertentu dengan banyak sampel.

\section{Populasi dan Sampel}

Penelitian ini dilakukan pada UMKM yang tergabung dalam Womanpreneur Comunnity (WPC) Kota Semarang. Dalam hal ini, WPC Semarang sebagai objek penelitian dikarenakan peran aktif wanita menjadi fokus utama khususnya dalam menjalankan usaha yang dapat menolong rumah tangga untuk memiliki lebih dari satu sumber penghasilan dalam rumah tangga tersebut. Akibatnya, pemasukan keuangan rumah tangga tidak hanya bergantung sepenuhnya pada suami. Selain itu, wanita di WPC Semarang ini merupakan kelompok aktif dan terus berkembang baik dalam jumlah anggota maupun keterlibatan mengikuti pembinaan atau seminar-seminar terkait UMKM. Adapun WPC Semarang adalah organisasi non-profit sebagai wadah bagi sahabat perempuan dalam meningkatkan kemandirian dan pemberdayaan ekonomi. Per Agustus 2019 WPC memiliki 150 anggota aktif yang terbagi dalam divisi kuliner, fashion, craft dan jasa. Untuk unit analisis pada penelitian ini menggunakan individu atau pelaku UMKM yang tergabung dalam WPC tersebut.

Penelitian ini menggunakan metode sampling dengan jumlah sampel berkisar 60 sampel. Jumlah sampel memperhatikan angka kecukupan sampel 
berdasarkan rumus slovin (Sevilla et al, 1960: 182) dan memperhatikan juga karakteristik populasi yang cenderung homogen dan kemampuan atau keterbatasan peneliti. Sampel yang diambil dalam penelitian ini harus memiliki kriteria sebagai berikut, (1) Sampel diambil dari UMKM yang tergabung dalam WPC Kota Semarang. (2) Sampel diambil dari UMKM yang telah menjalankan usahanya minimal 1 tahun. (3) Responden minimal berusia 25 tahun. (4) Responden minimal memiliki tingkat pendidikan SMP. Adapun jumlah sampel ditentukan menggunakan Rumus Slovin, dengan perhitungan sebagai berikut:

$\mathrm{N}=\mathrm{N} /\left(1+\mathrm{Ne}^{2}\right)$

dimana $\mathrm{n}=$ jumlah sampel, $\mathrm{N}=$ populasi, $\mathrm{e}=\operatorname{error}($ alpha)

Dalam penelitian ini ditentukan tingkat alpha adalah 10 persen atau confidence level peneliti 90 persen, maka diperoleh sampel minimal

$$
\begin{aligned}
\mathrm{n}=150 /\left(1+\left(150 \times 0,1^{2}\right)\right. & =150 / 1+(150 \times 0,01) \\
& =150 /(1+1,5) \\
& =60
\end{aligned}
$$

Berdasarkan rumus tersebut, sampel penelitian ini berjumlah 60 sampel.

\section{Instrumen Penelitian}

Instrumen penelitian yang digunakan dalam penelitian ini adalah kuesioner. Kuesioner dalam penelitian ini disusun dengan cara melakukan modifikasi dari kuesioner penelitian dulu yang relevan. Pengukuran instrumen penelitian dari kuesioner disajikan dengan skala likert (sangat setuju, setuju, tidak setuju, sangat tidak setuju). Instrumen-instrumen penelitian yang digunakan dalam penelitian ini adalah sebagai berikut (Christensen dan Knezek, 2009).

\section{Pengukuran Instrumen Penelitian}

Tabel 1 sampai dengan Tabel 4 menyajikan indikator-indikator pengukuran masing-masing instrumen penelitian 
Tabel 1. Indikator Antusiasme dan Produktivitas

\begin{tabular}{ll}
\hline No & \multicolumn{1}{c}{ Indikator } \\
\hline 1. & Pandangan bahwa bekerja dengan komputer menyenangkan \\
2. & Keinginan belajar komputer \\
3. & Perasaan senang belajar komputer \\
4. & Pandangan bahwa semakin dilatih belajar komputer maka akan semakin baik \\
5. & Pandangan bahwa belajar komputer membutuhkan kesabaran \\
6. & Keinginan bekerja dengan komputer \\
7. & Pandangan bahwa bekerja dengan komputer akan meningkatkan produktivitas \\
8. & Perasaan sangat membutuhkan komputer dalam melakukan pekerjaan \\
9. & Kepercayaan bahwa belajar komputer penting
\end{tabular}

\section{Tabel 2. Indikator Computer Anxiety}

\begin{tabular}{cl}
\hline No & \multicolumn{1}{c}{ Indikator } \\
\hline 1. & Perasaan takut melakukan kesalahan yang tidak dapat diperbaiki \\
2. & Perasaan asing dengan komputer \\
3. & Perasaan takut merusak atau kehilangan data di komputer \\
4. & Perasaan sulit memahami aspek teknis komputer \\
5. & Perasaan sulit memahami tombol-tombol di komputer \\
6. & Perasaan takut ketergantungan komputer \\
7. & Perasaan tegang dan gugup bekerja dengan komputer \\
8. & Perasaan tidak nyaman bekerja dengan komputer \\
\hline
\end{tabular}

\section{Tabel. 3 Indikator Keahlian Menggunakan Komputer}

\begin{tabular}{cl}
\hline No & \multicolumn{1}{c}{ Indikator } \\
\hline 1. & Keahlian terbiasa menggunakan komputer atau laptop pribadi \\
2. & Kemampuan menjalankan software akuntansi \\
3. & Kemampuan penggunaan panduan pengguna \\
4. & Kemampuan memasukkan atau menyimpan data di komputer \\
5. & Kemampuan log in dan log out dari software \\
6. & Kemampuan membuka dan menutup file komputer \\
7. & Kemampuan memahami istilah terkait perangkat keras \\
8. & Kemampuan memahami istilah terkait software atau aplikasi \\
9. & Kemampuan menggunakan media penyimpanan eksternal secara mandiri \\
10. & Kemampuan mencetak pekerjaan dengan printer secara mandiri \\
11. & Kemampuan membuat, mengubah, menghapus file di komputer secara mandiri \\
12. & Kemampuan penggunaan komputer untuk analisis data atau angka \\
13. & Kemampuan penggunaan komputer pengumpulan dan pengorganisiran informasi \\
14. & Kemampuan bekerja menggunakan aplikasi \\
& (pengolah kata, spreadsheet, presentasi, database, multimedia, web, browser, \\
15. & media komunikasi, sosial media) \\
& Frekuensi bekerja menggunakan aplikasi \\
& forum online, pesan teks, telepon atau voice call, video call, games)
\end{tabular}


Tabel 4. Indikator Kewajiban Perpajakan

\begin{tabular}{cl}
\hline No & \multicolumn{1}{c}{ Indikator } \\
\hline 1. & Kemampuan menggunakan aplikasi e-SPT \\
2. & Kemampuan menggunakan aplikasi e-form \\
3. & Kemampuan menggunakan aplikasi e-filling \\
4. & Kemudahan mengoperasikan e-SPT, e-form, e-filling \\
5. & Minat menggunakan e-SPT, e-form, e-filling \\
6. & Kejelasan menggunakan e-SPT, e-form, e-filling \\
7. & Tampilan e-SPT, e-form, e-filling mudah dipahami \\
8. & Akses e-SPT, e-form, e-filling mudah dipahami \\
9. & Usaha yang ringan atau mudah mengakses e-SPT, e-form, e-filling \\
10. & Ketepatan mengoperasikan e-SPT, e-form, e-filling \\
11. & Kemudahan mempelajari cara penggunaan e-SPT, e-form, e-filling \\
12. & Kemudahan menggunakan e-SPT, e-form, e-filling secara terampil \\
13. & Tingkat kerumitan sistem e-SPT, e-form, e-filling \\
14. & Ketepatan mengoperasikan e-SPT, e-form, e-filling sesuai kebutuhan \\
\hline
\end{tabular}

\section{Metode Analisis Data}

Metode analisis dalam penelitian ini disesuaikan dengan tujuan penelitian yang hendak dicapai. Untuk menjawab tujuan pertama, terkait pada profil digital UMKM Kota Semarang yang tergabung dalam WPC maka digunakan metode deskriptif kuantitatif dengan tabulasi silang. Sedangkan, untuk menjawab tujuan kedua terkait dengan ada tidaknya korelasi antara keahlian menggunakan komputer dengan kesiapan pelaporan pajak elektronik pada UMKM yang tergabung dalam WPC maka digunakan analisis korelasi.

\section{Uji Korelasi}

Uji signifikansi koefisien korelasi digunakan untuk menguji apakah besarnya hubungan antar variabel yang diuji sama dengan nol. Adapun apabila hubungannya sama dengan nol maka hal tersebut menunjukkan bahwa hubungan antar variabel sangat lemah dan tidak berarti. Sebaliknya, apabila hubungannya secara signifikan berbeda dengan nol maka hubungan tersebut kuat (Santoso, 2004). Dalam penelitian ini, untuk mengetahui hubungan antar satu variabel dengan variabel lain maka dilakukan uji analisis korelasi. Data yang digunakan yaitu data interval atau rasio dengan nilai korelasi nol sampai satu. Menurut Sugiyono (2010), intepretasi hasil koefisien korelasi dapat dijabarkan sebagai berikut: (1) 0,00-0,199: sangat rendah/sangat lemah. (2) 0,20-0,399:rendah/lemah. (3) 0,40-0,599: sedang. (4) 0,60-0,799: kuat. (5) 0,80-1,000: sangat kuat. 


\section{Hasil dan Pembahasan}

\section{Gambaran Digital UMKM Yang Tergabung Dalam WPC Kota Semarang}

Karakteristik responden meliputi usia, pekerjaan, pendidikan, rutinitas penggunaan komputer, koneksi responden terhadap internet, kepemilikan NPWP, pelaporan SPT tahunan, dan metode pelaporan SPT. Dalam penelitian ini (lampiran tabel 1), mayoritas responden berusia di atas 42 tahun sebanyak 40 orang dengan persentase 66,6 persen dan usia responden yang paling sedikit adalah yang berusia sekitar 25-30 tahun dan sekitar 31-36 tahun yaitu sebanyak 3 orang dengan persentase 5 persen. Sedangkan dalam kriteria pendidikan, mayoritas tingkat pendidikan responden berada pada jenjang SMA yaitu sebanyak 23 orang dengan persentase 28,3 persen dan responden paling sedikit dalam kriteria pendidikan yaitu SMP yang berjumlah 9 orang dengan persentase 15 persen.

Dari segi tingkat rutinitas dan keterbiasaan penggunaan komputer para pelaku UMKM yang tergabung dalam WPC cenderung masih sedikit yaitu sekitar 28 persen, sedangkan yang tidak memanfaatkan komputer sekitar 72 persen. Pada kenyatannya, pelaku UMKM yang tergabung dalam WPC memang jarang memanfaatkan penggunaan komputer dan lebih memilih cara manual dalam kesehariannya sehingga hal ini dapat memberi pengaruh pula pada pemahaman fungsionalitas dan kemampuan pengoperasian komputer.

Terkait dengan data responden yang tidak terhubung dengan internet, ratarata pelaku UMKM yang tergabung dalam WPC tidak memiliki komputer yang terhubung dengan internet. Hal ini ditunjukkan bahwa sebesar 53 persen responden yang tidak terkoneksi internet dan sebesar 47 persen responden yang terhubung dengan internet.

Dari segi kepemilikan NPWP, kebanyakan pelaku UMKM yang tergabung dalam WPC belum memenuhi kewajibannya sebagai wajib pajak. Hal ini ditunjukkan dengan persentase pelaku UMKM yang tidak memiliki NPWP yaitu 63 persen dan pelaku UMKM yang memiliki NPWP hanya 37 persen. Sedangkan untuk pelaporan SPT tahunan, pelaku UMKM yang tergabung dalam WPC dinyatakan bahwa belum semuanya melaporkan SPT tahunan. Hasil survei menemukan jika terdapat sebesar 67 persen yang tidak melaporkan SPT tahunan dan hanya sekitar 33 persen yang melakukan pelaporan SPT. Dengan demikian, dapat dikatakan bahwa pelaku UMKM yang memiliki NPWP juga masih cenderung melakukan pelaporan SPT secara manual dibandingkan dengan e-filling, e-form atau e-SPT. 


\section{Analisis Statistik Deskriptif}

\section{Tabel 5 . Statistik Deskriptif}

\begin{tabular}{|c|c|c|c|c|c|c|c|c|c|}
\hline \multirow{3}{*}{$\begin{array}{c}\text { Indikator } \\
\text { Antusiasme } \\
\text { dan } \\
\text { Produktivitas } \\
\text { (AP) }\end{array}$} & \multicolumn{4}{|c|}{ Skala Pengukuran } & \multirow{3}{*}{$\begin{array}{c}\text { Indikator } \\
\text { Computer } \\
\text { Anxiety } \\
\text { (CA) }\end{array}$} & \multicolumn{4}{|c|}{ Skala Pengukuran } \\
\hline & STS & TS & $S$ & SS & & STS & TS & S & SS \\
\hline & $\%$ & $\%$ & $\%$ & $\%$ & & $\%$ & $\%$ & $\%$ & $\%$ \\
\hline AP1 & 1,7 & 6,7 & 58,3 & 33,3 & CA1 & 13,3 & 56,7 & 28,3 & 1,7 \\
\hline AP2 & 0 & 1,7 & 43,3 & 55 & CA2 & 20 & 63,3 & 15 & 1,7 \\
\hline AP3 & 0 & 3,3 & 60 & 36,7 & CA3 & 13,3 & 53,3 & 31,7 & 1,7 \\
\hline AP4 & 0 & 3,3 & 53,3 & 43,3 & CA4 & 5 & 40 & 51,7 & 3,3 \\
\hline AP5 & 0 & 3,3 & 55 & 41,7 & CA5 & 11,7 & 71,7 & 15 & 1,7 \\
\hline AP6 & 0 & 8,3 & 68,3 & 23,3 & CA6 & 16,7 & 61,7 & 18.3 & 3,3 \\
\hline AP7 & 0 & 5 & 61,7 & 33,3 & CA7 & 16,7 & 68,3 & 13,3 & 1,7 \\
\hline AP8 & 1,7 & 5 & 66,7 & 26,7 & CA8 & 20 & 70 & 8,3 & 1,7 \\
\hline AP9 & 0 & 3,3 & 63,3 & 33,3 & & & & & \\
\hline \multirow{3}{*}{$\begin{array}{c}\text { Indikator } \\
\text { Keahlian } \\
\text { Menggunakan } \\
\text { Komputer (KK) }\end{array}$} & \multicolumn{4}{|c|}{ Skala Pengukuran } & Indikator & \multicolumn{4}{|c|}{ Skala Pengukuran } \\
\hline & STS & TS & S & SS & $\begin{array}{c}\text { Kemampu } \\
\text { an }\end{array}$ & STS & TS & S & SS \\
\hline & $\%$ & $\%$ & $\%$ & $\%$ & $\begin{array}{l}\text { Bekerja } \\
\text { Mengguna } \\
\text { kan } \\
\text { Komputer } \\
\text { (TK) }\end{array}$ & $\%$ & $\%$ & $\%$ & $\%$ \\
\hline KK1 & 3,3 & 35 & 48,3 & 13,3 & TK1 & 36,7 & 35 & 26,7 & 1,7 \\
\hline KK2 & 5 & 48,3 & 41,7 & 5 & TK2 & 36,7 & 33,3 & 30 & 0 \\
\hline KK3 & 1,7 & 33,3 & 56,7 & 8,3 & TK3 & 50 & 28,3 & 18,3 & 3,3 \\
\hline KK4 & 0 & 30 & 55 & 15 & TK4 & 55 & 28,3 & 16,7 & 0 \\
\hline KK5 & 0 & 30 & 63,3 & 6,7 & TK5 & 50 & 33,3 & 16,7 & 0 \\
\hline KK6 & 0 & 18,3 & 68,3 & 13,3 & TK6 & 58,3 & 26,7 & 15 & 0 \\
\hline KK7 & 1,7 & 36,7 & 53,3 & 8,3 & TK7 & 26,7 & 25 & 41,7 & 6,7 \\
\hline KK8 & 3,3 & 38,3 & 51,7 & 6,7 & TK8 & 20 & 28,3 & 40 & 11,7 \\
\hline KK9 & 0 & 25 & 60 & 15 & TK9 & 21,7 & 28,3 & 41,7 & 8,3 \\
\hline KK10 & 0 & 28,3 & 51,7 & 20 & & & & & \\
\hline KK11 & 0 & 28,3 & 56,7 & 15 & & & & & \\
\hline KK12 & 1,7 & 33,3 & 51,7 & 13,3 & & & & & \\
\hline KK13 & 0 & 26,7 & 56,7 & 16,7 & & & & & \\
\hline
\end{tabular}

Sumber: data primer diolah (2020) 


\section{Keterangan:}

*AP1 (pemikiran bahwa bekerja dengan komputer menyenangkan), AP2 (keinginan belajar komputer), AP3 (perasaan senang belajar komputer), AP4 (semakindilatih belajar komputer akan semakin baik), AP5 (belajar komputer membutuhkan kesabaran), AP6 (keinginan bekerja dengan komputer), AP7 (peningkatan produktivitas dengan komputer), AP8 (kebutuhan akan komputer untuk bekerja), AP9 (kepercayaan pentingnya belajar komputer).

*CA1 (ketakutan membuat kesalahan yang tidak dapat diperbaiki), CA2 (perasaan asing dengan komputer), CA3 (ketakutan merusak/kehilangan informasi di komputer), CA4 (kesulitan memahami aspek teknis komputer), CA5 (kesulitan memahami tomboltombol di komputer), CA6 (ketakutan ketergantungan dengan komputer), CA7 (perasaan tegang dan gugup bekerja dengan komputer), CA8 (perasaan tidak nyaman bekerja dengan komputer).

*KK1 (kebiasaan bekerja dengan laptop/komputer pribadi), KK2 (kemampuan menjalankan software akuntansi), KK3 (kemampuan penggunaan panduan pengguna), KK4 (kemampuan memasukkan data/meyimpan data di file komputer), KK5 (kemampuan log in dan log out dari software), KK6 (kemampuan membuka dan menutup file komputer), KK7 (pemahaman mengenai istilah terkait perangkat keras), KK8 (pemahaman mengenai istilah terkait software/aplikasi), KK9 (kemampuan penggunaan media penyimpanan eksternal secara mandiri), KK10 (kemampuan mencetak pekerjaan dengan printer secara mandiri), KK11 (kemampuan membuat, mengubah, menghapus file di komputer secara mandiri), KK12 (kemampuan penggunaan komputer untuk analisis data/angka), KK13 (kemampuan penggunaan komputer untuk pengumpulan dan pengorganisir informasi).

*TK1 (pengolah kata), TK2 (spreadsheet), TK3 (presentasi), TK4 (database), TK5 (multimedia), TK6 (desain web), TK7 (mesin pencari di internet), TK8 (komunikasi), TK9 (sosial media).

\section{Antusiasme dan Produktivitas dalam Menggunakan Komputer}

Antusiasme dimaknai sebagai bentuk minat dari para pelaku UMKM yang tergabung dalam WPC dalam menggunakan komputer. Minat penggunaan komputer yang tinggi dapat membantu mendorong pemahaman, penguasaan dan keterampilan teknologi, terutama dalam mengoptimalkan produktivitas kerja (Indah 2017). Berdasarkan jawaban semua responden, pada tabel 2 (indikator antusiasme dan produktivitas) menunjukkan bahwa antusiasme dan produktivitas penggunaan komputer dari para pelaku UMKM yang tergabung dalam WPC dinyatakan cukup baik. Hal ini ditandai dengan banyak responden yang memilih setuju di masing-masing indikator. Dalam konteks ini, para pelaku UMKM yang tergabung dalam WPC telah menunjukkan betapa besar antusias mereka dalam menggunakan komputer, walaupun sebagian besar dari mereka cenderung tidak memiliki komputer dan bahkan masih melaporkan pajak secara manual. 
Mereka merasa bahwa ada peningkatan produktivitas kerja ketika memanfaatkan perangkat komputer dimana mampu mendorong serta mengarahkan para pelaku UMKM tersebut agar lebih siap terhadap teknologi informasi khususnya dalam peran mereka untuk melaporkan pajak secara elektronik. Roosdhani (2012) pun menyatakan bahwa dampak positif yang timbul melalui adanya minat yang tinggi dalam memanfaatkan teknologi informasi ini mampu mendukung bisnis yang dijalankan. Hal serupa juga diperkuat oleh Syahyuni (2017), yang menyatakan bahwa apabila seseorang menguasai penggunaan teknologi maka hal tersebut dapat menunjang produktivitas kerjanya.

\section{Computer Anxiety}

Computer anxiety lebih pada bentuk rasa cemas dan takut seseorang ketika menggunakan komputer sehingga mereka cenderung merasa mendapat manfaat yang lebih sedikit dari penggunaan komputer. Tingkat kecemasan terhadap komputer dari para pelaku UMKM yang tergabung dalam WPC cenderung rendah. Secara umum, pelaku UMKM yang tergabung dalam WPC di Kota Semarang tidak merasa takut atau kesulitan dalam menggunakan komputer, bahkan mereka juga merasa nyaman apabila bekerja dengan komputer. Hal ini terlihat dari jumlah responden lebih banyak memilih merasa tidak setuju apabila mereka merasa cemas atau takut dalam menggunakan komputer. Walaupun pelaku UMKM memiliki tingkat computer anxiety yang rendah, tetapi mereka tetap mengalami kendala ketika harus memahami aspek teknis komputer. Sedangkan Sudaryono dan Astuti (2005) mengatakan bahwa seseorang yang memiliki tingkat computer anxiety yang tinggi akan menunjukkan tingkat keahlian yang lebih rendah, sebaliknya seseorang yang memiliki tingkat computer anxiety yang rendah akan menunjukkan tingkat keahlian yang lebih tinggi.

\section{Keahlian Menggunakan Komputer}

Keahlian menggunakan komputer diartikan sebagai tingkat kemampuan seseorang dalam penggunaan komputer beserta sistem operasi baik software/aplikasi maupun perangkat keras hingga penyimpanan data dan penggunaan tombol keyboard (Indriantoro 2000). Berdasarkan indikator keahlian komputer, bahwa para pelaku UMKM yang tergabung dalam WPCmemang memiliki kemampuan dalam menggunakan komputer, namun belum secara mendalam terutama terkait dengan kemampuan menggunakan aplikasi. Dengan kata lain, pelaku UMKM yang tergabung dalam WPC masih belum mampu untuk menjalankan software atau aplikasi akuntansi. Adapun tingkat keahlian seseorang dalam menggunakan komputer dapat membantu meningkatkan kinerjanya. Hal ini juga disampaikan oleh Syahyuni (2017), yang 
menyatakan bahwa apabila seseorang mudah menguasai penggunaan teknologi (komputer) dapat menunjang produktivitas kerjanya.

\section{Tingkat Kemampuan Bekerja Menggunakan Aplikasi}

Tingkat kemampuan bekerja dengan aplikasi menunjukkan tentang kemampuan seseorang memanfaatkan media dalam arti aplikasi atau software yang ada di komputer. Adapun pemanfaatan aplikasi tersebut diharapkan dapat membantu seseorang agar lebih mudah dalam melakukan pekerjaannya. Dari hasil penelitian dapat dilihat bahwa pelaku UMKM dinilai tidak mampu untuk menggunakan atau mengoperasikan aplikasi yang ada di komputer seperti pengolah kata, spreadsheet, presentasi, database, multimedia, dan desain web. Namun temuan lainnya menyatakan bahwa pelaku UMKM yang tergabung dalam WPC cenderung terbiasa dan ahli dalam memanfaatkan aplikasi yang ada untuk pencarian data di internet, berkomunikasi, dan akses sosial media.

\section{Tabel 6. Statistik Deskriptif}

\begin{tabular}{ccccccc}
\hline $\begin{array}{c}\text { Indikator } \\
\text { Frekuensi } \\
\text { Bekerja } \\
\text { Menggunakan }\end{array}$ & $\begin{array}{c}\mathbf{1} \\
\text { (tdk } \\
\text { prnh) }\end{array}$ & $\begin{array}{c}\mathbf{2} \\
\text { (jrg) }\end{array}$ & $\begin{array}{c}\mathbf{3} \\
(1-2 / \mathrm{bln})\end{array}$ & $\begin{array}{c}\mathbf{4} \\
(1-2 / \mathrm{mg})\end{array}$ & $\begin{array}{c}\mathbf{5} \\
(3-4 / \mathrm{mg})\end{array}$ & $\begin{array}{c}\mathbf{6} \\
(\mathrm{stp} \mathrm{hr})\end{array}$ \\
(FREK) & & & & & & \\
\hline FREK1 & & & & & & \\
FREK2 & 41,7 & 21,7 & 3,3 & 8,3 & 8,3 & 16,7 \\
FREK3 & 21,7 & 21,7 & 10 & 8,3 & 1,7 & 16,7 \\
FREK4 & 50 & 26,7 & 3,3 & 8,3 & 5 & 35 \\
FREK5 & 45 & 25 & 1,7 & 0 & 8,3 & 15 \\
FREK6 & 45 & 23,3 & 1,7 & 13,3 & 5 & 8,3 \\
FREK7 & 53,3 & 26,7 & 0 & 6,7 & 1,7 & 16,7 \\
FREK8 & 11,7 & 21,7 & 5 & 1,7 & 1,7 & 8,3 \\
FREK9 & 3,3 & 8,3 & 3,3 & 5 & 6,7 & 73,3 \\
FREK10 & 3,3 & 16,7 & 6,7 & 0 & 5 & 68,3 \\
FREK11 & 5 & 33,3 & 8,3 & 5 & 6,7 & 41,7 \\
FREK12 & 40 & 30 & 1,7 & 6,7 & 3,3 & 18,3 \\
\hline
\end{tabular}

Sumber: data primer diolah (2020)

\section{Keterangan:}

*FREK1 (pengolah kata), FREK2 (e-mail), FREK3 (mesin pencari di internet), FREK4 (database), FREK5 (spreadsheet), FREK6 (multimedia), FREK7 (blog), FREK8 (group/forum diskusi online), FREK9 (pesan teks), FREK10 (telepon/voice call), FREK11 (video call), FREK12 (game komputer/android/IOS). 


\section{Frekuensi Bekerja Menggunakan Aplikasi}

Dalam konteks ini, frekuensi bekerja dengan aplikasi menunjukkan seberapa sering seseorang menggunakan dan memanfaatkan aplikasi yang ada, khususnya aplikasi atau software yang ada pada komputer. Berdasarkan tabel 3, ditemukanpelaku UMKM sejauh ini masih memanfaatkan aplikasi atau software pada konteks penggunaan untuk berkomunikasi dan mencari informasi. Adapun aplikasi tersebut antara lain seperti grup/forum diskusi online, pesan teks, voice call (telepon), video call, dan mesin pencari di internet, sedangkan aplikasi dalam arti untuk membantu bekerja seperti pengolah kata, e-mail, database, spreadsheet, multimedia, blog, dan game di komputer hampir tidak pernah mereka manfaatkan atau gunakan.

\section{Tabel 7. Statistik Deskriptif}

\begin{tabular}{ccccc}
\hline $\begin{array}{c}\text { Indikator } \\
\text { Kewajiban }\end{array}$ & STS & TS & S & SS \\
Pajak (KP) & $(\%)$ & $(\%)$ & $(\%)$ & $(\%)$ \\
\hline KP1 & 15 & 55 & 26,7 & 3,3 \\
KP2 & 15 & 58,3 & 23,3 & 3,3 \\
KP3 & 16,7 & 56,7 & 25 & 1,7 \\
KP4 & 13,3 & 60 & 26,7 & 0 \\
KP5 & 8,3 & 40 & 45 & 6,7 \\
KP6 & 16,7 & 61,7 & 20 & 1,7 \\
KP7 & 11,7 & 61,7 & 26,7 & 0 \\
KP8 & 11,7 & 63,3 & 25 & 0 \\
KP9 & 13,3 & 66,7 & 18,3 & 1,7 \\
KP10 & 13,3 & 70 & 15 & 1,7 \\
KP11 & 13,3 & 60 & 23,3 & 3,3 \\
KP12 & 13,3 & 60 & 25 & 1,7 \\
KP13 & 13,3 & 55 & 30 & 1,7 \\
KP14 & 13,3 & 56,7 & 25 & 5 \\
\hline
\end{tabular}

Sumber: data primer diolah (2020)

\section{Keterangan:}

*KP1 (kemampuan menggunakan aplikasi e-SPT), KP2 (kemampuan menggunakan aplikasi e-form), KP3 (kemampuan menggunakan aplikasi e-filling), KP4 (kemudahan mengoperasikan e-filling/e-form/e-SPT), KP5 (minat menggunakan e-filling/e-form/eSPT), KP6 (kejelasan menggunakan e-filling/e-form/e-SPT), KP7 (tampilan e-filling/eform/e-SPT mudah dipahami), KP8 (interaksi dengan e-filling/e-form/e-SPT mudah dipahami), KP9 (usaha yang ringan dalam berinteraksi dengan e-filling/e-form/e-SPT), KP10 (ketepatan mengoperasikan e-filling/e-form/e-SPT), KP11 (kemudahan mempelajari cara penggunaan e-filling/e-form/e-SPT) , KP12 (kemudahan menggunakan e-filling/e-form/e-SPT secara terampil), KP13 (sistem e-filling/eform/e-SPT tidak rumit), KP14 (ketepatan mengoperasikan e-filling/e-form/e-SPT sesuai kebutuhan). 


\section{Kewajiban Pajak}

Kewajiban pajak dalam konteks ini lebih pada keharusan bagi wajib pajak baik secara perorangan maupun badan untuk menghitung, menyetor, dan melaporkan pajaknya. Adapun bentuk pelaporan kewajiban pajak dalam variabel ini lebih diutamakan untuk pelaporan pajak secara elektronik dan online seperti $e$-filling, $e$-form, dan e-SPT. Dapat disimpulkan bahwa sebenarnya para pelaku UMKM memiliki minat yang cukup tinggi untuk melaporkan pajak secara online/elektronik dengan menggunakan e-filling, e-form, dan e-SPT. Hal ini juga ditandai dengan kesadaran mereka untuk mengurus NPWP (sebanyak 37 persen dari pelaku UMKM tersebut yang memiliki NPWP). Namun, mereka masih kurang memahami dan merasa kesulitan untuk menggunakan serta mengoperasikan pelaporan pajak secara online/elektronik tersebut sehingga hal ini membuat pelaku UMKM cenderung mengabaikan atau tidak memanfaatkan pelaporan SPT secara online/elektronik yang ada. Pernyataan ini juga didukung oleh Andi (2018) yang menyatakan bahwa peningkatan minat wajib pajak dalam penggunaan sistem pelaporan online (khususnya e-filling) didominasi oleh kemudahan dan kejelasan dari pemahaman cara melakukan penyampaian SPT online/elektronik.

\section{Tabel 8. Hasil Nilai Korelasi}

\begin{tabular}{|c|c|c|c|c|c|}
\hline $\begin{array}{c}\text { Antusiasme } \\
\text { dan } \\
\text { produktivitas } \\
\text { pada kesiapan } \\
\text { pelaporan } \\
\text { pajak } \\
\text { elektronik }\end{array}$ & $\begin{array}{l}\text { Computer } \\
\text { anxiety } \\
\text { pada } \\
\text { kesiapan } \\
\text { pelaporan } \\
\text { pajak } \\
\text { elektronik }\end{array}$ & $\begin{array}{c}\text { Keahlian } \\
\text { menggunakan } \\
\text { komputer } \\
\text { pada kesiapan } \\
\text { pelaporan } \\
\text { pajak } \\
\text { elektronik }\end{array}$ & $\begin{array}{c}\text { Kemampuan } \\
\text { bekerja } \\
\text { mengguna- } \\
\text { kan aplikasi } \\
\text { pada } \\
\text { kesiapan } \\
\text { pelaporan } \\
\text { pajak } \\
\text { elektronik }\end{array}$ & $\begin{array}{l}\text { Frekuensi } \\
\text { bekerja } \\
\text { mengguna- } \\
\text { kan aplikasi } \\
\text { pada } \\
\text { kesiapan } \\
\text { pelaporan } \\
\text { pajak } \\
\text { elektronik }\end{array}$ & $\begin{array}{c}\text { Literasi } \\
\text { digital pada } \\
\text { kesiapan } \\
\text { pelaporan } \\
\text { pajak } \\
\text { elektronik }\end{array}$ \\
\hline 0,224 & $-0,192$ & 0,357 & 0,214 & 0,113 & 0,221 \\
\hline
\end{tabular}

Sumber: data primer diolah (2020)

\section{Korelasi Antara Antusiasme dan Produktivitas dalam Menggunakan Komputer Dengan Kesiapan Pelaporan Pajak Elektronik}

Berdasarkan hasil pengujian, menunjukkan bahwa antusiasme dan produktivitas dalam menggunakan komputer memiliki korelasi dengan kesiapan pelaporan pajak elektronik. Hal ini dapat dilihat dari koefisien korelasi yang memiliki nilai sebesar 0,224 . Hasil tersebut memiliki arti bahwa terdapat hubungan antara antusiasme dan produktivitas pelaku UMKM yang tergabung dalam WPC di Kota Semarang dalam menggunakan komputer terhadap kesiapan mereka dalam melaporkan pajak secara elektronik. Hasil pengujian ini juga menyatakan bahwa korelasinya lemah sehingga kedua 
variabel dinilai memiliki hubungan yang cenderung tidak signifikan. Rasa antusias dan produktivitas dari para pelaku UMKM yang tergabung dalam WPC Kota Semarang dalam menggunakan komputer terhadap kesiapan mereka untuk melakukan pelaporan pajak elektronik dinilai masih kurang dan perlu dilakukan upaya untuk meningkatkannya. Adapun rasa antusiasme dan produktivitas yang tinggi memberi dampak positif bagi pengembangan para pelaku UMKM baik bagi diri pribadi maupun bagi usaha mereka.

Secara diri pribadi, pelaku UMKM akan menambah pengetahuan dan ketrampilan dalam memanfaatkan teknologi informasi yang ada khususnya komputer dan bagi usaha mereka sendiri, hal tersebut akan mempermudah mereka dalam menjalankan atau mengelola bisnis terutama dalam kesiapan pelaporan pajak elektronik (e-filling, e-form dan e-SPT). Hal ini didukung pula oleh Indah (2017) yang menyatakan bahwa rasa antusias menciptakan minat yang tinggi serta manfaat dalam menggunakan komputer dimana mampu mendorong penguasaan dan pemahaman serta ketrampilan teknologi seseorang. Dengan demikian, dapat dikatakan bahwa apabila pelaku UMKM dapat meningkatkan antusiasme dan produktivitas menggunakan komputer maka tingkat kesiapan mereka dalam melaporkan pajak secara elektronik akan lebih besar.

\section{Korelasi Antara Computer Anxiety Dengan Kesiapan Pelaporan Pajak Elektronik}

Computer anxiety memiliki korelasi yang lemah dengan kesiapan pelaporan pajak elektronik. Hal ini tampak dari koefisien korelasi yang memiliki nilai sebesar -0,192. Hasil pengujian ini juga menunjukkan bahwa korelasi antara computer anxiety dan pelaporan pajak elektronik memiliki arah hubungan yang berlawanan. Ini menunjukkan saat individu memiliki tingkat computer anxiety yang tinggi, maka kesiapan pelaporan pajak justru rendah. Dalam hal ini, tingkat computer anxiety ditandai dengan rasa cemas untuk menggunakan komputer dan kecemasan terkait hal-hal teknis dalam penggunaan komputer. Hasil survei menunjukkan computer anxiety pelaku UMKM yang tergabung dalam WPC di Kota Semarang cukup rendah. Sudaryono dan Astuti (2005) yang mengatakan bahwa seseorang yang memiliki tingkat computer anxiety yang tinggi akan menunjukkan tingkat keahlian yang lebih rendah, sebaliknya seseorang yang memiliki tingkat computer anxiety yang rendah akan menunjukkan tingkat keahlian yang lebih tinggi. Dengan demikian para pelaku UMKM yang tergabung dalam WPC sebenarnya memiliki tingkat keahlian penggunaan komputer yang memadai.

Meskipun demikian, hasil penelitian ini menunjukkan sekalipun memiliki tingkat computer anxiety yang rendah, kesiapan pemenuhan kewajiban 
perpajakan dari para responden juga rendah. Hal ini selaras dengan hasil uji korelasi yang menunjukkan bahwa hubungan antara kedua variabel ini sangat lemah. Hal ini menunjukkan kesiapan pemenuhan kewajiban perpajakan yang harus dipenuhi responden secara elektronik tidak berkorelasi dengan kemampuan teknis mereka dalam menggunakan komputer. Hasil ini juga menunjukkan ada faktor lain yang berkorelasi erat dengan kesiapan pemenuhan kewajiban pajak elektronik. Desmayanti (2012) menyatakan munculnya rasa kurang percaya atau rasa tidak menerima manfaat dari sistem pelaporan pajak elektronik disinyalir sebagai alasan mengapa seseorang ragu untuk menggunakannya. Maka hasil penelitian ini menunjukkan ada faktorfaktor lain yang lebih berperan dalam mendukung kesiapan pemenuhan kewajiban pajak elektronik.

\section{Korelasi Antara Keahlian Menggunakan Komputer Dengan Kesiapan Pelaporan Pajak Elektronik}

Keahlian menggunakan komputer memiliki korelasi dengan kesiapan pelaporan pajak elektronik. Hal ini dapat dilihat dari koefisien korelasi yang memiliki nilai sebesar 0,357. Hasil ini menyatakan bahwa keahlian menggunakan komputer dari pelaku UMKM wanita di Kota Semarang berhubungan lemah terhadap kesiapan dalam melaporkan pajak secara elektronik. Berdasarkan hasil penelitian tersebut, keahlian penggunaan komputer dari para pelaku UMKM baik mulai dari pengoperasian komputer beserta software hingga penyimpanan data dan pencetakan hasil dinilai lemah sehingga menyebabkan tingkat kesiapan mereka terhadap pelaporan pajak secara elektronik pun rendah. dengan kata lain, belum semua pelaku UMKM menggunakan pelaporan pajak elektronik karena kurangnya keahlian dalam menggunakan komputer. Kurangnya keahlian menggunakan komputer diindikasi karena kurangnya pula pengalaman para pelaku UMKM dalam menggunakan atau memanfaatkan teknologi informasi khususnya komputer. Seperti halnya yang diungkapkan oleh Sugihanti (2011) bahwa ketika wajib pajak memiliki pengalaman yang sedikit tentang teknologi maka akan membuat ia tidak tertarik menggunakan pelaporan pajak elektronik (e-filling). Terlebih lagi, adanya kecenderungan pola pikir yang menganggap penggunaan sistem komputer dalam pelaporan pajak akan lebih menyulitkan para pelaku UMKM (Utami dan Maria 2017).

\section{Korelasi Antara Tingkat Kemampuan Bekerja Menggunakan Aplikasi Dengan Kesiapan Pelaporan Pajak Elektronik}

Tingkat kemampuan bekerja menggunakan aplikasi memiliki korelasi dengan kesiapan pelaporan pajak elektronik. Hal ini tampak dari koefisien korelasi yang memiliki nilai sebesar 0,214 . Hasil ini dapat diartikan bahwa tingkat 
kemampuan pelaku UMKM yang tergabung dalam WPC di Kota Semarang dalam bekerja menggunakan aplikasi memiliki hubungan yang lemah terhadap kesiapan mereka untuk melaporkan pajak secara elektronik.

Kemampuan bekerja menggunakan aplikasi diukur dari mampu atau tidaknya para pelaku UMKM dalam memanfaatkan aplikasi atau software yang ada. Dalam konteks ini, aplikasi yang dimaksud antara lain seperti aplikasi pengolah kata, spreadsheet, presentasi, database, multimedia, dan desain web. Sesuai dengan hasil penelitian, sebagian besar pelaku UMKM dinilai memiliki kemampuan yang lemah dalam penggunaan aplikasi/software yang ada. Hal ini ternyata berdampak pula dari kesiapan mereka ketika harus melaporkan pajak secara elektronik. Menurut Desmayanti (2012), adapun keterbatasan kemampuan ini disebabkan karena adanya anggapan pengguna bahwa penggunaan aplikasi (sistem pelaporan pajak elektronik) dipandang rumit dimana semakin rumit sistem, maka semakin rendah tingkat penggunaannya.

\section{Korelasi Antara Frekuensi Bekerja Menggunakan Aplikasi Dengan Kesiapan Pelaporan Pajak Elektronik}

Frekuensi bekerja menggunakan aplikasi memiliki korelasi dengan kesiapan pelaporan pajak elektronik. Hal ini tampak dari koefisien korelasi yang memiliki nilai sebesar 0,113. Hasil ini menyatakan bahwa frekuensi bekerja menggunakan aplikasi berhubungan sangat lemah terhadap kesiapan pelaku UMKM yang tergabung dalam WPC di Kota Semarang dalam melaporkan pajak secara elektronik. Dalam hal ini, tingkat frekuensi bekerja menggunakan aplikasi dari para pelaku UMKM dinilai sangat jarang terutama untuk aplikasi selain yang dipakai berkomunikasi. Tingkat jarangnya bekerja dengan menggunakan aplikasi membuat para pelaku UMKM juga mengalami kesulitan untuk menguasai bahkan memiliki keahlian bekerja menggunakan komputer beserta aplikasi dalam kesehariaannya, terlebih lagi ketika mereka harus dihadapkan pada pelaporan pajak secara elektronik. Hal ini juga didukung oleh pernyataan Utami dan Maria (2017), yang menyatakan bahwa memang belum semua wajib pajak mampu menggunakan pelaporan pajak elektronik karena mereka belum terbiasa (jarang) mengaplikasikan teknologi baru yang tersedia.

\section{Korelasi Literasi Digital Secara Keseluruhan Dengan Kesiapan Pelaporan Pajak Elektronik}

Literasi digital dalam konteks ini lebih pada kemampuan untuk menemukan, mengatur dan membuat informasi menggunakan teknologi digital seperti internet, telepon seluler, perangkat keras dan lunak dari komputer, PDA, dan perangkat digital lainnya (Warlick, 2004). Dengan kata lain, literasi digital menunjukkan seberapa jauh individu atau kelompok terbiasa menggunakan atau memanfaatkan sistem dan aplikasi komputer. Berdasarkan tabel 5 
ditunjukkan bahwa secara simultan terdapat korelasi antara literasi digital dengan kesiapan pelaporan pajak elektronik. Hal ini dapat dilihat dari hasil koefisien korelasi yang memiliki nilai sebesar 0,221. Hasil ini menyatakan bahwa tingkat literasi digital para pelaku UMKM yang tergabung dalam kelompok Womanpreneur Community (WPC) di Kota Semarang memiliki hubungan yang lemah terhadap kesiapan dalam melakukan pelaporan pajak secara elektronik.

Dalam hal ini, secara keseluruhan literasi digital para pelaku UMKM yang tergabung dalam WPC di Kota Semarang dinilai rendah dimana pemahaman dan penggunaan komputer beserta aplikasinya masih kurang. Pelaku UMKM yang tergabung dalam WPC cenderung hanya memanfaatkan teknologi yang ada untuk berkomunikasi dan bertukar informasi namun dalam mengelola bisnis serta kesehariannya sangat jarang dimanfaatkan. Akibatnya, ketika dihadapkan pada situasi dalam pelaporan pajak secara elektronik maka mereka menjadi tidak siap. Kecenderungannya adalah mereka akan melaporkan pajak secara manual dimana dibantu oleh konsultan pajak. Menurut Desmayanti (2012), kesiapan teknologi pada dasarnya dipengaruhi oleh individu itu sendiri, apakah dari dalam diri individu siap menerima teknologi khususnya dalam hal ini pelaporan pajak elektronik. Apabila seseorang dapat menerima sebuah teknologi dengan baik maka ia cenderung tidak ragu-ragu untuk melaporkan pajak secara elektronik. Lebih lanjut Desmayanti (2012) mengatakan bahwa kesiapan teknologi informasi juga mempengaruhi kemajuan pola pikir individu dimana semakin siap individu dalam menerima teknologi yang baru maka semakin maju pula pemikirannya terutama dalam beradaptasi dengan teknologi yang semakin berkembang.

\section{Simpulan}

\section{Simpulan}

Hasil penelitian ini menunjukkan bahwa pada pelaku UMKM yang tergabung dalam kelompok Womanpreneur Community (WPC), literasi digital memiliki korelasi yang lemah terhadap kesiapan pelaporan pajak secara elektronik. Literasi digital dalam penelitian diukur dari antusiasme, tingkat kecemasan, serta tingkat keahlian teknis dalam menggunakan komputer dan aplikasi. Dengan demikian, hasil penelitian ini menunjukkan ada faktor lain yang berkorelasi dengan kesiapan pelaporan pajak elektronik. Korelasi yang lemah ini menunjukkan bahwa literasi digital tidak berperan banyak dalam kesiapan para pelaku UMKM yang tergabung dalam kelompok WPC untuk melakukan kewajiban pelaporan pajak elektroniknya. Para pelaku UMKM tersebut hanya memanfaatkan teknologi yang ada untuk berkomunikasi dan bertukar informasi bukan untuk pengelolaan bisnis. Minat para pelaku UMKM yang 
tergabung dalam kelompok WPC untuk melaporkan kewajiban pajak secara elektronik juga berkorelasi lemah dengan kemampuan teknis mereka dalam menggunakan komputer. Hal ini membuktikan bahwa faktor kemampuan teknis tidak mejadi penghalang bagi para responden untuk memenuhi kewajiban perpajakan secara elektronik. Dengan demikian, kesiapan pemenuhan pelaporan kewajiban perpajakan berkorelasi dengan faktor lain selain literasi digital.

\section{Keterbatasan}

Beberapa hal yang menjadi keterbatasan dalam penelitian ini, yaitu (1) Literasi digital hanya mengukur kemampuan teknis seseorang dalam menggunakan komputer dan mengorganisasi informasi yang didapatkan, sehingga tidak mengukur kemampuan responden untuk menganalisa informasi yang telah didapatkan. (2) Skala usaha responden sangat bervariasi dan mempengaruhi kewajiban perpajakan yang harus dilakukan oleh responden dimana kewajiban perpajakan elektronik yang berbeda memerlukan tingkat kesiapan yang berbeda pula, akibatnya penelitian ini kurang dalam memberi gambaran yang lebih rinci terkait hal tersebut.

\section{Saran}

Berdasarkan kesimpulan dan keterbatasan yang terdapat dalam penelitian ini, maka saran yang dapat diberikan bagi penelitian yang akan datang antara lain (1) Memperluas definisi dan pengukuran literasi digital agar dapat mencakup kemampuan responden untuk menganalisa informasi serta meneliti faktorfaktor non teknis yang berkorelasi dengan kesiapan pelaku UMKM untuk memenuhi kewajiban pajak secara elektronik. (2) Melakukan uji korelasi di dalam skala usaha dan jenis usaha yang sama untuk mendapatkan gambaran yang lebih rinci mengenai literasi digital dan kesiapan pelaku UMKM dalam memenuhi kewajiban pajak secara elektronik. Bagi Kantor Pelayanan Perpajakan (KPP), saran yang dapat diberikan sebagai hasil penelitian ini adalah KPP sebaiknya berfokus pada pengembangan pengetahuan non teknis seperti pengetahuan perpajakan dari para pelaku UMKM.

\section{Daftar Pustaka}

Andi. 2018. Kemampuan Wajib Pajak Orang Pribadi Dalam Menggunakan E-Filling. Jurnal Ekonomi-Qu (Jurnal Ilmu Ekonomi) 8 (2).

Christensen, R.W., \& Knezek, G.A. 2009. Construct Validity for The Teachers' Attitudes Toward Computer Questionnaire. Journal of Computing in Teacher Education $25(4)$.

Desmayanti, Esy. 2012. Faktor-Faktor Yang Mempengaruhi Penggunaan Fasilitas EFilling Oleh Wajib Pajak Sebagai Sarana Penyampaian SPT Masa Secara Online 
dan Real Time (Kajian Empiris di Wilayah Kota Semarang). Skripsi. Fakultas Ekonomi Universitas Diponegoro Semarang.

Holzer, M., \& Kathe C. 1998. Government at Work: Best Practices and Model Programs. London: Sage Publication.

Indah, Agus T. 2017. Pengaruh Ketrampilan Teknologi Terhadap Produktivitas Kerja Pada Sub Bagian Evaluasi dan Pengembangan Sumber Daya Manusia Direktorat Jenderal Pertumbuhan UMKM Jakarta. Widya Cipta I (2).

Indriantoro, Nur. 2000. Pengaruh Komputer Anxiety terhadap Keahlian Dosen dalam Pengunaan Komputer", Jurnal Akuntansi dan Auditing Indonesia 4 (2).

Kemdikbud. 2017. Jakarta: Sekretariat TIM GLN Kemdikbud, 8.

Kuncoro, Mudrajad. 2010. Dasar-dasar Ekonomika Pembangunan. Yogyakarta: UPP STIM YKPN.

Nasikin, Mochamad. 2016. Praktik Penyusunan Laporan Keuangan Pada UMKM Kuliner di UMKM Ishokuiki Kota Tuban. Tugas Akhir. Sekolah Tinggi Ilmu Ekonomi Perbanas Surabaya.

Roosdhani, W., et.all. 2012. Analisis Tingkat Penggunaan Teknologi Informasi dan Komunikasi pada Usaha Kecil Menengh Di Kab. Jepara. Jurnal Dinamika Ekonomi \& Bisnis 9 (2).

Rustiana. 2004. Computer Self Efficacy (CSE) Mahasiswa Akuntansi dalam Penggunaan Teknologi Informasi: Tinjauan Perspektif Gender. Jurnal Akuntansi dan Keuangan 6 (1).

Santoso, Singgih. 2004. Mengatasi Berbagai Masalah Statistik dengan SPSS Versi 11,5. Jakarta: Elex Media Komputindo.

Sevilla, C. G. et.al 2007. Research Methods. Rex Printing Company. Quezon City.

Sudaryono, E. A., Istiati D. A. 2005. Pengaruh Computer Anxciety terhadap Keahlian Karyawan Bagian Akuntansi dalam Menggunakan Komputer. Simposium Nasional Akuntansi VIII Solo.

Sugihanti, Winna. 2011. Analisis Faktor-Faktor Yang Mempengaruhi Minat Perilaku Wajib Pajak Untuk Menggunakan E-Filling (Studi Empiris Pada Wajib Pajak Badan Kota Semarang). Skripsi. Fakultas Ekonomi Universitas Diponegoro Semarang.

Sugiyono. 2010. Metode Penelitian Kuantitatif, Kualitatif dan R\&D. Bandung: Alfabeta.

Syahyuni. 2017. Pengaruh Budaya Organisasi dan Komunikasi terhadap Kinerja Karyawan pada PT Fastfood Indonesia Tbk. (KFC Cabang Demang Lebar Daun) Palembang. Jurnal Kompetitif 6 (1), 128-143.

Tambunan, Tulus T.H. 2002. Usaha Kecil dan Menengah di Indonesia, Beberapa Isu Penting. Jakarta: Salemba Empat.

Undang-Undang Usaha Mikro Kecil Menengah No. 20 tahun 2008.

Utami, Adisti P, Maria S.O. biagi. Analisa Faktor-Faktor Yang Mempengaruhi Penggunaan E-Filling Wajib Pajak Orang Pribadi (Studi Pada Wajib Pajak Orang Pribadi Yang Berdomisili di Kota Tangerang). Ultima Accounting 9 (2).

Warlick, F. D. 2004. Redefining Literacy for the 21st Century. Linworth Publishing. Santa Barbara, CA.

Zuhdiar, Laeis. 2019. Setiap tahun tumbuh 2.000 UMKM di Kota Semarang dikutip dari https://jateng.antaranews.com, diakses 02/10/2019. 


\section{Lampiran}

Tabel 9. Karakteristik Responden

\begin{tabular}{ccl}
\hline Karakteristik & Jumlah & Persentase (\%) \\
\hline Usia 25-30 tahun & 3 & 5 \\
31-36 tahun & 2 & 3,33 \\
37-42 tahun & 15 & 25 \\
Di atas 42 tahun & 40 & 66,67 \\
& & \\
Pendidikan SMP/SLTP & 9 & 15 \\
SMA/SMK & 23 & 28,33 \\
Diploma & 10 & 16,67 \\
S1/S2 & 18 & 30 \\
& & \\
\hline Sumber: data primer diolah (2020) & &
\end{tabular}

\section{Gambar 1 Karakteristik Responden}

Data Rutinitas Penggunaan Komputer

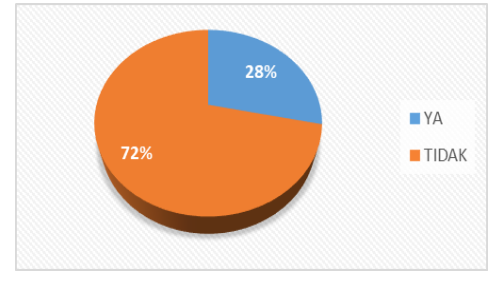

Data Responden yang Terhubung Internet

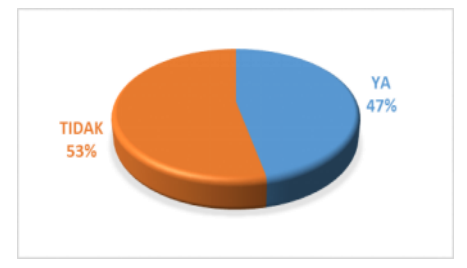

Data Kepemilikan NPWP

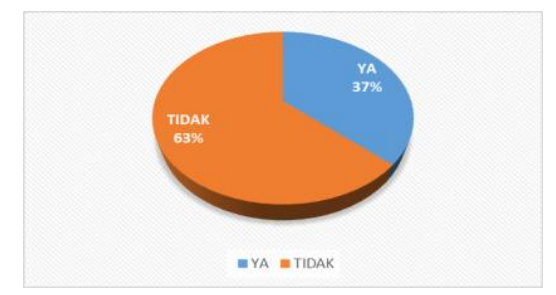

Data Pelaporan dan Metode Pelaporan SPT

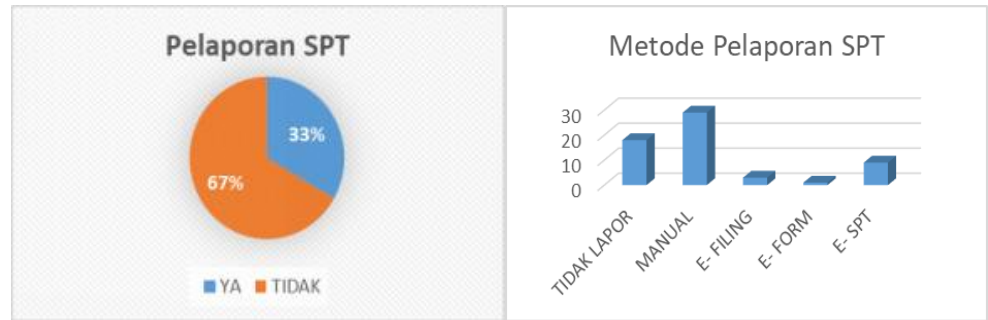

Sumber: data primer diolah (2020) 